\title{
Synergistic Study of Hydroxyiron (III) and Kaolinite Composite for the Adsorptive Removal of Phenol and Cadmium
}

\author{
Egah Godwin Ogbaji”, Baba Nwunuji Hikon, Ngantem Godfrey Sheckhar, \\ Emmanuel Amuntse Yerima, Omovo Mavis, Ogah Ekirigwe, Aminu Fatai Ayodeji \\ Department of Chemical Science, Federal University Wukari, Wukari, Nigeria \\ Email address: \\ egah.godwin@yahoo.com (G. O. Egah), babahikon@fuwukari.edu.ng (B. N. Hikon), ngantemgodfrey12@gmail.com (G. S. Ngantem), \\ yerimaemmanuel@yahoo.com (E. A. Yerima), mavomovo@yahoo.com (M. Omovo), uhinyohe@gmail.com (E. Ogah), \\ oluwashinatunde@rocketmail.com (F. A. Aminu) \\ ${ }^{*}$ Corresponding author
}

\section{To cite this article:}

Egah Godwin Ogbaji, Baba Nwunuji Hikon, Ngantem Godfrey Sheckhar, Emmanuel Amuntse Yerima, Omovo Mavis, Ogah Ekirigwe, Aminu Fatai Ayodeji. Synergistic Study of Hydroxyiron (III) and Kaolinite Composite for the Adsorptive Removal of Phenol and Cadmium. International Journal of Environmental Chemistry. Vol. 3, No. 1, 2019, pp. 30-42. doi: 10.11648/j.ijec.20190301.15

Received: April 10, 2019; Accepted: May 29, 2019; Published: June 18, 2019

\begin{abstract}
This research used raw kaolinite (RK), thermally activated Kaolinite (TAK), hydroxyiron (iii) kaolinitecomposite (HKC), as adsorbent for the adsorption of phenol and cadmium from aqueous solutions over a concentration range of 5-25 mg/l and 10-50 mg/l respectively. Effect of initial $\mathrm{pH}$ on the adsorbates was carried out at $\mathrm{pH} \mathrm{2-11} \mathrm{at} \mathrm{(298} \mathrm{K),} \mathrm{and}$ adsorbent dosage from $0.5-2.5 \mathrm{~g}$ with $50 \mathrm{ml}$ adsorbate solution. Adsorption thermodynamics were developed for $25-55^{\circ} \mathrm{C}$ for 5-25 mg/L and 10-50 mg/L of phenol and cadmium solutions for $1 \mathrm{hr}$ for all the adsorbents. The Physicochemical characteristics of RK, TAK and HKC were shown to be: $\mathrm{pH} 7.38,7.26$ and 7.20; pHzpc: 11.00, 10.50 and 10.10; Conductivity $(2 \mu / \mathrm{cm}): 1.656,1.660$ and 1.657; Bulky density $\left(\mathrm{g} / \mathrm{cm}^{3}\right): 1.186,1.111$ and 1.214; Attrition (\%): $17.49,26.53$ and 27.21 respectively. X-ray fluorescence (XRF), Fourier transformed infrared spectroscopy (FTIR) and Scanning electron microscope (SEM) techniques were used to determine adsorbent features. The presence of hydroxyl, carboxylic, hydrogen bonding and aldehyde group showed that adsorbents bonds phenol and cadmium. At equilibrium, the maximum percentage removal for phenol: RK (52.020\%), TAK (63.468\%), HKC (79.952\%) and cadmium: RK (41.980\%), TAK (48.398\%), HKC (65.830\%) respectively were achieved for contact time. From the experiment adsorption capacities were found to increase with increase in temperature, contact time and concentration. The equilibrium adsorption data fitted the Langmuir better than the Freundlich model. The calculated thermodynamic parameters -Enthalpy change entropy change and Gibbs free energy, adsorption of both phenol and cadmium was not spontaneous but endothermic, meaning the chemisorption dominates physosorption. Adsorption kinetics was better explained by the Blanchard pseudo-second order kinetic model than the Lagergren first order. Overall, the adsorption of phenol was more favourable than for cadmium for all adsorbents.
\end{abstract}

Keywords: Adsorption, Kaolinite, Hydroxyiron (III), Phenol, Cadmium, Kinetic, Thermodynamic, Isotherm

\section{Introduction}

The problem of phenol and cadmium pollutant in wastewater has become a major source of concern to researchers. This is because they are considered as toxic, hazardous and priority pollutant [1]. The wastewaters discharged from soap, pesticide, solvent, pharmaceuticals, paint, paper industries and water disinfecting process constitute a major source of phenol pollutant in water [2]. Phenol is highly soluble and mobile in water. Small amount of it may cause severe diseases like cancer, vomiting, nausea, paralysis, smoky colored urine [3]. According to US Environmental Protection Agency (EPA), the maximum permitted concentration level of phenol is $1 \mu \mathrm{g} / \mathrm{L}$ for drinking water and $0.5-1 \mathrm{mg} / \mathrm{L}$ for industrial wastewater [1].

Cadmium on the other hand, due to its high toxicity, non- 
biodegradable and bio-accumulation, has cause health problems to living organisms [4]. Sources, toxicity and adverse effects of cadmium have been widely documented [2, $5,6]$.

Various methods for the removal of water pollutants such as ion exchange, solvent extraction, reverse osmosis, ultrafiltration, nano-filtration, chemical precipitation, coagulation, flocculation, floatation, electro-dialysis, membrane filtration, biological oxidation, complexing, and adsorption have been reviewed by Rao et al., [7].

One of the physicochemical treatment method used for pollutant removal is Adsorption method. This is due to their low cost and high efficiency [8]. Kaolinites are considered as good absorbents and used in water pollution remediation processes due to their high rate of adsorption, ion-exchange capacity, large surface area, high versatility, easily manipulated properties, and low costs [9]. The major aimed of this research is to develop a low cost adsorbent for the removal of phenol and Cadmium using Hydroxyiron (III) $\left(\mathrm{Fe}(\mathrm{OH})_{3}\right)$ calcined with kaolinites. Batch adsorption experiment was used to determine the effect of initial $\mathrm{pH}$, contact time, adsorbent dosage, initial concentration and temperature. Further in this research, equilibrium isotherm models were used to describe the adsorption processes.

\section{Adsorption Isotherms}

\subsection{Freundlich Isotherm}

The Freundlich isotherm model assumes that the removal of metal ions occurs on a heterogeneous adsorbent surface and can be applied to multilayer adsorption [10]. It can also be used for both mono-layer and multi-layer adsorption. Linear equation of Freundlich isotherm was adopted by Sha'Ato et al., [3]. This is given as Equation 1.

$$
\log Q_{e}=\frac{1}{n_{f}} \log c_{e}+\log K_{f}
$$

Where $\mathrm{Q}_{\mathrm{e}}(\mathrm{mg} / \mathrm{g})$ is the amount of adsorbate adsorbed per unit mass of adsorbent and $\mathrm{C}_{\mathrm{e}}(\mathrm{mg} / \mathrm{L})$ is the concentration at equilibrium. $K_{f}$ is the Freundlich constants related to the adsorption capacity and $\mathrm{n}_{\mathrm{f}}$ the adsorption intensity [11]. A linear plot of $\log Q_{e}$ versus $\log C_{e}$ gives $n_{F}$ as the slope and $K_{f}$ as the intercept. When values of $\mathrm{n}$ are within the ranges of 1 10 , they are referred to as good adsorption intensity [3].

\subsection{Langmuir Isotherm}

This is used for monolayer adsorption onto a surface containing a finite number of identical binding sites [12]. The Langmuir adsorption model is expressed as shown in Equation 2.

$$
\frac{1}{Q_{e}}=\frac{1}{Q_{m}}+\frac{1}{C_{e}} \times \frac{1}{b Q_{m}}
$$

Where $\mathrm{Q}_{\mathrm{m}}(\mathrm{mg} / \mathrm{g})$ represents the total number of binding sites available for sorption, $\mathrm{C}_{\mathrm{e}}$ is the equilibrium concentration of the adsorbate in bulk solution $(\mathrm{mg} / \mathrm{L}), \mathrm{Q}_{\mathrm{e}}$ $(\mathrm{mg} / \mathrm{g})$ is the amount of adsorbate adsorbed per unit mass of the adsorbent at equilibrium and $b(\mathrm{~L} / \mathrm{mg})$ is the AdsorbateAdsorbent Langmuir constant. The higher the value of $b$, the higher the heat of sorption that leads to formation of stronger bond [3].

A linear plot of $1 / Q_{e}$ versus $1 / C_{e}$ gives a straight line graph, in which $1 / \mathrm{Q}_{\mathrm{m}}$ is the slope and $1 / \mathrm{bQ}$ the intercept. The langmuir isotherm characteristics are determined by the dimensionless constant known as separation factor, $\mathrm{R}_{\mathrm{L}}$. This is expressed as Equation 3.

$$
R_{L}=\frac{1}{\left(1+b_{C_{0}}\right)}
$$

Where $\mathrm{b}(\mathrm{L} / \mathrm{mg})$ is the Langmuir constant for adsorbateadsorbent and $\mathrm{C}_{0}(\mathrm{mg} / \mathrm{L})$ the initial adsorbate concentration. If $\mathrm{R}_{\mathrm{L}}>1$, the adsorption is unfavourable, $\mathrm{R}_{\mathrm{L}}=1$, adsorption is linear, $\mathrm{R}_{\mathrm{L}}$ between $0-1$, adsorption is favourable and $\mathrm{R}_{\mathrm{L}}=$ 0 , adsorption is irreversible [3].

\subsection{Adsorption Kinetics Studies}

Chemical kinetics is a method used to determine how experimental conditions affect the rate of chemical reaction [10]. Pseudo-first-order and pseudo-second-order kinetic models were used to analyze the experimental data and model of the adsorption processes [13].

\subsubsection{Pseudo First Order Model}

The Pseudo first order model is sometimes applied in liquid-solid phase adsorption experiment for adsorbateadsorption [14], [15]. The Lagergren first-order equation was calculated using Equation 4.

$$
\log \left(Q_{e}-Q_{t}\right)=\log Q_{e}-\frac{K_{1}}{2.303} t
$$

Where $\mathrm{Q}_{\mathrm{e}}$ represents the amount of adsorbate adsorbed per unit mass of the adsorbent in $(\mathrm{mg} / \mathrm{g}), \mathrm{Q}_{\mathrm{t}}$ the amount of adsorbate that was adsorbed per unit of the adsorbent $(\mathrm{mg} / \mathrm{g})$ at contact time $\mathrm{t}(\mathrm{min})$ and $\mathrm{k}_{1}$ the pseudo first order rate constant $(\mathrm{L} / \mathrm{min})$. A linear plot of $\log \left(\mathrm{Q}_{\mathrm{e}}-\mathrm{Q}_{\mathrm{t}}\right)$ versus $\mathrm{t}$ gives the rate constant $\mathrm{k}_{1}$, while $\log \mathrm{Q}_{\mathrm{e}}$ represents the intercept and $-\mathrm{k}_{1} / 2.303$ the slope [15].

\subsubsection{Blanchard Pseudo-Second Order Model}

The pseudo second order equation was stated by Bai et al [16]. This was calculated using Equation 5.

$$
\frac{t}{Q_{t}}=\frac{1}{K_{2} Q_{e^{2}}}+\frac{1}{Q_{e}} t
$$

Where $\mathrm{Q}_{\mathrm{t}}$, Qe and $\mathrm{t}$ retained their usual meanings as stated in first order model. $\mathrm{K}_{2}\left(\mathrm{~g} \cdot \mathrm{mg}^{-1} \cdot \mathrm{min}^{-1}\right)$ is the pseudo-second rate constant and $\mathrm{h}(\mathrm{mg} / \mathrm{g} \cdot \mathrm{min})=\mathrm{K}_{2} \mathrm{Q}_{\mathrm{e}}{ }^{2}$ is the initial adsorption rate. A linear plot of $t / Q_{t}$ Versus $t$, gives $K_{2}$ as the second- order rate constant, $1 / \mathrm{k}_{2} \mathrm{Q}_{\mathrm{e}}{ }^{2}$ as the intercept and $1 / \mathrm{Q}_{\mathrm{e}}$ as the slope [16].

\subsection{Thermodynamics of Adsorption}

The thermodynamics parameters such as enthalpy change 
$\Delta \mathrm{H}^{0}$ in $\left(\mathrm{kJmol}^{-1}\right)$, the entropy change $\Delta \mathrm{S}^{0}$ in $\left(\mathrm{JK}^{-1} \mathrm{~mol}^{-1}\right)$ and free energy change $\Delta \mathrm{G}^{0}$ in $\left(\mathrm{kJmol}^{-1}\right)$, helps to better describe the adsorption processes [17]. Thermodynamics was calculated using Equation 6.

$$
\log \left(\frac{q_{e}}{C_{e}}\right)=\frac{\Delta S^{\circ}}{2.303 R}-\left(\frac{\Delta H^{\circ}}{2.303 R}\right) \frac{1}{T}
$$

Where $\Delta \mathrm{H}^{\circ}$ and $\Delta \mathrm{S}^{\circ}$ retained their usual meanings, log $\left(q_{\mathrm{e}} / c_{\mathrm{e}}\right)$ as the adsorption affinity, $\mathrm{R}$ is the universal gas constant $\left(8.314 \mathrm{Jmol}^{-1} \mathrm{~K}^{-1}\right)$ and $\mathrm{T}$ the temperature in $(\mathrm{K})$. A linear plot of $\log \left(q \mathrm{e} / C_{\mathrm{e}}\right)$ versus $1 / T$ gives a straight line graph where $\left(\Delta S^{0} / 2.303 R\right)$ is the intercept and- $\left(\Delta H^{0} / 2.303 R\right)$ is the slope [18]. The Free Gibbs Energy is expressed as in Equation 7.

$$
\Delta G^{\circ}=\Delta H^{\circ}-T \Delta S^{\circ}
$$

Where; T (k) is the standard temperature taken to be $298 \mathrm{~K}$ [17].

\section{Methods}

\subsection{Sampling and Sample Identification}

The raw Kaolinite used in this work was supplied by Somak industries Nigeria limited, Akoko-Edo L. G. A, Edo State, Nigeria. Sample identification was done by the Department of Soil Science, Federal University Wukari, Taraba State.

\subsection{Adsorbents Preparation}

For the preparation of raw kaolinite (RK), $3 \mathrm{~kg}$ of the raw kaolinite was washed thoroughly with distilled water in order to remove any dissolved impurities, dried in an oven at $110^{\circ} \mathrm{C}$ for $24 \mathrm{hrs}$ and crushed and sieved using $50 \mathrm{~mm}$ mesh sieve [3]. The raw kaolinite was stored as RK in an air tight container for future use.

Thermally activated kaolin (TAK), was used as control. In preparation, one (1) $\mathrm{kg}$ of the raw kaolinite was calcined in a muffle furnace at $600^{\circ} \mathrm{C}$ for $1 \mathrm{hr}$. It was then cooled, sealed in an air tight container and labeled as TAK for future use.

In the preparation of Hydroxyiron (III) $\left(\mathrm{Fe}(\mathrm{OH})_{3}\right.$, anhydrous ferric chloride $\left(\mathrm{FeCl}_{3}\right)$ solution was reacted with Sodium Hydroxide $\mathrm{NaOH}$ solution to form a reddish-brown precipitate which was filtered using filter paper, oven-dried for about $24 \mathrm{hrs}$ and crushed to powdered form. This was stored in an air tight container and labeled as $\mathrm{Fe}(\mathrm{OH})_{3}$.

The hydroxyiron (III)-kaolinite composite (HKC) was prepared by thoroughly mixing hydroxyiron (III) $\left(\mathrm{Fe}(\mathrm{OH})_{3}\right)$ with raw kaolinite at ratio $3: 1$ and calcined in muffle furnace at $600^{\circ} \mathrm{C}$ for $1 \mathrm{hr}$, cooled and stored in an air tight container for future use. The yield was calculated from Equation 8 .

$$
\text { Percentage yield }=\frac{\text { calcined weight }}{\text { Raw material weight }} \times 100
$$

\subsection{Physicochemical Characterization of Adsorbents}

\subsection{1. $\mathrm{pH}$}

The $\mathrm{pH}$ determination for the adsorbents, $1.0 \mathrm{~g}$ of the absorbent was added to $100 \mathrm{~mL}$ distilled water in a beaker and stirred using magnetic stirrer for $1 \mathrm{hr}$. The $\mathrm{pH}$ was then measured and recorded in triplicates using $\mathrm{HI} 8014 \mathrm{pH}$ meter (Hanna instruments) [3].

\subsection{2. pH at Zero Point Charge ( $\mathrm{pH}_{Z P C}$ )}

$\mathrm{pHzpc}$ of an adsorbent is important because it indicates the net surface charge of the adsorbent in solution [19]. The $\mathrm{pHzpc}$ is the point where the curve of $\mathrm{pH}$ (final) vs $\mathrm{pH}$ (initial) intersects [3]. In the determination of $\mathrm{pH}$ at zero point charge, buffer solution of different $\mathrm{pH}$ 's $\left(\mathrm{pH}_{\text {Initial }}\right)$ values of 4,7 and 10 , was added to $0.5 \mathrm{~g}$ of the adsorbent each separately, shaked for $2 \mathrm{hrs}$ and measured as $\mathrm{pH}_{\text {Final }}$. A relation of $\mathrm{pH}_{\text {Initial }}$ on $\mathrm{X}$-axis and $\mathrm{pH}_{\text {final }}-\mathrm{pH}_{\text {initial }}$ on $\mathrm{Y}$-axis was plotted. The intercept on $\mathrm{X}$-axis was taken as the zero point charge.

\subsubsection{Conductivity ( $\mu \mathrm{S} / \mathrm{cm})$}

For Conductivity measurement, $1.0 \mathrm{~g}$ of the adsorbent was added to distilled water, mixed for 20 minutes and its conductivity measured in two micro-Siemen per centimeter ( $2 \mu \mathrm{S} / \mathrm{cm}$ ) using DDS-307 Conductivity meter (Pec Medicals USA).

\subsubsection{Bulk Density}

Bulk density was determined using the tamping method [3]. A $5 \mathrm{~g}$ of each adsorbent was packed in a $10 \mathrm{ml}$ measuring cylinder to a known volume and tapped until a minimum volume was occupied. The apparent volume is read to the nearest unit. Bulk density was measured using Equation 9.

$$
\text { Bulk density }\left(\mathrm{g} / \mathrm{cm}^{3}\right)=\frac{\text { Adsorbent mass }(\mathrm{g})}{\text { Adsorbent apparent volume }\left(\mathrm{cm}^{3}\right)}
$$

\subsubsection{Percentage Attrition (\%)}

This is referred to as measure of the mechanical strength and it is a parameter used to describe adsorbent ability to withstand normal handling operations [3]. The attrition of the adsorbents was measured by wet attrition method [20]. A 1.0 $\mathrm{g}$ of the adsorbent was measured into $100 \mathrm{ml}$ of distilled water in a conical flask. The solution was stirred using a magnetic stirrer for $2 \mathrm{hrs}$. The solution was then filtered with filter paper and the residue adsorbent was dried at room temperature for $12 \mathrm{hrs}$. Percentage attrition was determined using Equation 10.

$$
\text { Attrition }(\%)=\frac{\text { Initial mass }(g)-\text { Final mass }(g)}{\text { Initial mass }(g)} \times 100
$$

\subsection{Batch Adsorption Experiment}

In batch experiment, different concentrations of $(10,20$, $30,40$ and $50 \mathrm{mg} / \mathrm{L})$ for cadmium and $(5,10,15,20$ and 25 $\mathrm{mg} / \mathrm{L}$ ) for phenol were prepared from the stock solution of $1000 \mathrm{mg} / \mathrm{L}$ and $100 \mathrm{mg} / \mathrm{L}$ respectively.

Drop-wise addition of $0.1 \mathrm{M} \mathrm{NaOH}$ and $0.1 \mathrm{M} \mathrm{HCl}$ was used for $\mathrm{pH}$ adjustment with the aid of Hanna digital $\mathrm{pH}$ meter until the desired $\mathrm{pH}$ value was obtained. The batch experiment was done by contacting $0.5 \mathrm{~g}$ of each adsorbent with $50 \mathrm{ml}$ solution of known adsorbate concentration in 
(250 ml) conical flask, and stirred for $(1 \mathrm{hr})$ contact time with the aid of mechanical shaker at room temperature until equilibrium was achieved. The solution was then filtered and the filtrates were analyzed using UV-visible spectrophotometer (Shimadzu, UV-1700 spectrophotometer) and atomic adsorption spectrophotometer (AAS) to determine the residual concentrations of Phenol and cadmium at a maximum wavelength of $270 \mathrm{~nm}$ and $228.8 \mathrm{~nm}$ respectively.

In this study, batch adsorption experiments were performed for $\mathrm{pH}$ in the range of 2-11, adsorbent dosage of range (0.5-2.5 g), contact time of range 10 - 60 minutes, temperature of range $25-55^{\circ} \mathrm{C}$ for both Phenol and cadmium respectively. While the concentration ranges are $5-25 \mathrm{mg} / \mathrm{L}$ and $10-50 \mathrm{mg} / \mathrm{L}$ for both phenol and Cadmium ion respectively. In each experiment, the studied parameter was varied while others were kept constant. The experiment was repeated in triplicate to minimize errors [21]. In the batch adsorption experiment, the amount $\mathrm{Q}_{\mathrm{e}}(\mathrm{mg} / \mathrm{g})$, of Phenol and Cadmium was expressed as equation 11 .

$$
Q_{e(m g / g)}=\frac{\left(C_{o}-C_{e}\right)}{M_{a}} v
$$

Where $\mathrm{Q}_{\mathrm{e}}$ represents adsorption capacity, $\mathrm{C}_{\mathrm{o}}$ and $\mathrm{C}_{\mathrm{e}}$ the initial and residual concentrations $(\mathrm{mg} / \mathrm{L})$ respectively, $V(\mathrm{~L})$ is the volume of solution used and $M_{a}(\mathrm{~g})$ the mass of adsorbent used for each batch treatment. The percentage removal of phenol and Cadmium was calculated using Equation 12.

$$
\text { Percentage Removal }(\%)=\frac{\left(C_{o}-C_{e}\right)}{C_{o}} \times 100
$$

Where $C_{o}$ and $C_{e}$ retained their usual meaning as seen in equation (11)

\section{Results and Discussions}

\subsection{Physicochemical Attributes of Adsorbents}

\subsection{1. $\mathrm{pH}$}

The $\mathrm{pH}$ indicates the nature of the adsorbents whether acidic or basic [3]. Results in Table 1, shows the $\mathrm{pH}$ of RK, TAK and HKC to be $(7.79,7.84$ and 7.37$)$ respectively, indicating neutrality for all the adsorbents. These results showed that the adsorbents are good adsorbents [22].

\subsection{2. $\mathrm{pHzpc}$}

This is a point where there is no charge and it is used to determine the surface charge of an adsorbent [20]. If pHzpc < $\mathrm{pH}$ adsorption is favoured, but when $\mathrm{pHzpc}>\mathrm{pH}$, the repulsive force would result in decrease in adsorption due to the positively charged surface of the adsorbent [3]. From Table 1 the $\mathrm{pH}$ at zero point charge ( $\mathrm{pHzpc}$ ) of the various adsorbents (RK, TAK and HKC) were found to be 10.20 , 10.50 and 11.00 respectively, indicating positively charged surface. Studies on aqueous phase abatement of phenol and cadmium using hydroxyiron (III) calcined separately with bentonite showed similar results [3].

\subsubsection{Conductivity ( $\mu \mathrm{S} / \mathrm{cm})$}

Conductivity is the amount of charges on the surface of an adsorbent [23]. From results in Table 1, the conductivity of RK, TAK, and HKC were found to be $(1.663,1.661$ and 1.763) $\mu \mathrm{S} / \mathrm{cm}$ respectively. High conductivity of adsorbent interferes with adsorption process [3]. But since all the values are low, it implies that all the adsorbents have good conduction for adsorption.

\subsubsection{Bulk Density $\left(\mathrm{g} / \mathrm{cm}^{3}\right)$}

This is an estimation of the packing volume of an adsorbent which determines the amount of adsorbate adsorbed to an adsorbent [21]. Lower bulk density values enhanced adsorbent regeneration ability when use [24]. Results in Table 1, showed the bulk density of RK, TAK and $\mathrm{HKC}$ to be $\left(1.191,1.000\right.$ and $\left.1.185 \mathrm{~g} / \mathrm{cm}^{3}\right)$ respectively, which are above $1 \mathrm{~g} / \mathrm{cm}^{3}$. Similar results of $\left(1.111 \mathrm{~g} / \mathrm{cm}^{3}\right)$ were reported suggesting that the adsorbents densities are good for adsorption processes [3].

\subsubsection{Percentage Attrition}

Percentage attrition is the relative percentage loss of an adsorbent that occurs during transportation and stirring [23]. It has been reported that, the lower the percentage attrition of adsorbents, the better its regeneration ability [3]. Results in Table 1, showed the percentage attrition of RK, TAK and HKC to be $(5.95 \%, 27.61 \%$ and $27.91 \%)$ respectively. These results are lower compared to (31.68\%) reported from studies on acid-activated almond shell based carbon ALA, which suggested that the adsorbents are good for adsorption since they have lesser abrasion losses during commercial utilization [23].

Table 1. Selected Physicochemical Attributes of Adsorbents.

\begin{tabular}{llll}
\hline Attribute & RK & TAK & HKC \\
\hline $\mathrm{pH}$ & 7.79 & 7.84 & 7.37 \\
$\mathrm{pH}$ & 10.20 & 10.50 & 11.00 \\
Conductivity $(2 \mu \mathrm{s} / \mathrm{cm})$ & 1.663 & 1.661 & 1.763 \\
Bulk-density $\left(\mathrm{g} / \mathrm{cm}^{3}\right)$ & 1.191 & 1.000 & 1.185 \\
$(\%)$ Attrition & 5.95 & 27.61 & 27.91 \\
\hline
\end{tabular}

\subsection{FTIR Analysis of Adsorbents}

The FT-IR analysis of adsorbents is shown in Table 2. The FTIR spectrum is important in identification of surface functional groups which plays a great role in adsorption mechanism and capacity [21]. Good adsorbents have specific properties such as large pores, availability of oxygen, hydrogen content and Hydroxyl group [21]. The FT-IR was carried using the $\mathrm{KBr}$ disk method [25]. 
For the FT-IR analysis of $\mathrm{Fe}(\mathrm{OH})_{3}$, in Figure 1. The peaks at $3850.04 \mathrm{~cm}^{-1}, 3726.60 \mathrm{~cm}^{-1}, 3595.43 \mathrm{~cm}^{-1}$ and $3286.81 \mathrm{~cm}^{-}$ ${ }^{1}$ within the frequency range of $\left(3000-4000 \mathrm{~cm}^{-1}\right)$ are due to stretching vibrations of O-H groups [3]. The band at 3850.04 $\mathrm{cm}^{-1}$ and $3726.60 \mathrm{~cm}^{-1}$ indicates $-\mathrm{OH}$ groups at the edge of the $\mathrm{Fe}(\mathrm{OH})_{3}$ platelets [5]. The bands at $3595.43 \mathrm{~cm}^{-1}$ and $3286.81 \mathrm{~cm}^{-1}$ are connected with the internal $-\mathrm{OH}$ stretching from hydroxyl groups [10]. The band at $1049.31 \mathrm{~cm}^{-1}$ is attributed to $\mathrm{Fe}-\mathrm{O}$ stretch in iron [15]. Studies on aqueous phase abatement of phenol and cadmium using hydroxyiron (III) calcined separately with bentonite reported similar results [3].

For the FT-IR of RK whose spectrum is shown in Figure 2, the broad peak at $3690.76 \mathrm{~cm}^{-1}$ ranging from $\left(3600-4000 \mathrm{~cm}^{-1}\right)$ is attributed to $-\mathrm{OH}$ stretch from alcohols or phenols groups coordinated to octahedral $\mathrm{Al}^{3+}$ cations [5]. The peaks at $2930.12 \mathrm{~cm}^{-1}, 2372.33 \mathrm{~cm}^{-1}$, and $1826.00 \mathrm{~cm}^{-1}$ are an indication of organic impurity in the kaolinite clay sample [26]. The band at $1633.33 \mathrm{~cm}^{-1}$ is attributed to $-\mathrm{OH}$ bend vibration from the kaolinite [27]. The broad band at $1018.00 \mathrm{~cm}^{-1}$ is ascribed to Si-O stretching vibration of silica [3]. The characteristic sharp bands at $919.79 \mathrm{~cm}^{-1}$ is assigned to the $\mathrm{Al}-\mathrm{O}-\mathrm{H}$ bending vibration (hydroxyl groups sitting on the alumina faces) of kaolinite [5]. The peak at $759.00 \mathrm{~cm}^{-1}$ is attributed to Si-O stretching from silica and $686.69 \mathrm{~cm}^{-1}$ are attributed to $-\mathrm{OH}$ group symmetric stretching vibration [28]. The peak at 545.00 $\mathrm{cm}^{-1}$ and $460.29 \mathrm{~cm}^{-1}$ are attributed Al-O-Si octahedral and SiO-Si bending vibration on the raw kaolinite [29].

The FT-IR spectrum of HKC shown in Figure 3, the bands at $3694.46 \mathrm{~cm}^{-1}$ correspond to $-\mathrm{OH}$ group from alcohol at the surface of the alumina octahedral layers that interact with the oxygen atoms of the adjacent silica tetrahedral layers (Al-O$\mathrm{H})$ [5]. The band at $3627.46 \mathrm{~cm}^{-1}$ is connected with the internal hydroxyl group. The bending vibrations of free water molecules adsorbed to hydroxyiron (III) - kaolinite composites surface are responsible for the bands at 3466.00 $\mathrm{cm}^{-1}$ which indicates absorption at the outer surface (hygroscopic moisture) of the hydroxyiron (III) - kaolinite composites [3]. The band at $1636.72 \mathrm{~cm}^{-1}$ is attributed to $\mathrm{OH}$ bends vibration [27]. The broad band at $1042.00 \mathrm{~cm}^{-1}$ is attributed to Si-O in-plane stretching vibration [26]. The characteristic sharp bands at $920.00 \mathrm{~cm}^{-1}$ is assigned to the $\mathrm{Al}-\mathrm{O}-\mathrm{H}$ bending vibration from hydroxyl groups sitting on the alumina faces of hydroxyiron (III) - kaolin composites sample [5]. The peak at $788.11 \mathrm{~cm}^{-1}$ is attributed to Si-O stretching from silica and $683.45 \mathrm{~cm}^{-1}$ is attributed to $-\mathrm{OH}$ symmetric stretching vibration [28]. The peak at $543.43 \mathrm{~cm}^{-1}$ and $461.86 \mathrm{~cm}^{-1}$ are attributed Al-O-Si octahedral and Si-OSi bending vibration [29].

Table 2. FT-IR Analysis of Adsorbents.

\begin{tabular}{|c|c|c|c|c|c|}
\hline Group Freq $\left(\mathrm{cm}^{-1}\right)$ & Functional groups & $\mathrm{Fe}(\mathrm{OH})_{3}$ & RK & HKC & Assignment \\
\hline \multirow[t]{4}{*}{$4000-3000$} & Alcohol/Phenol & 3850.04 & - & - & Free $\mathrm{OH}$ stretch \\
\hline & Alcohol/Phenol & 3726.60 & - & 3694.46 & $\mathrm{O}-\mathrm{H}$ stretch \\
\hline & Alcohol/Phenol & 3595.43 & 3690.76 & 3627.46 & $\mathrm{O}-\mathrm{H}$ stretch \\
\hline & Alcohol/Phenol & - & - & 3466.00 & $-\mathrm{OH}$ stretch \\
\hline $1680-1620$ & Alkenes & - & 1633.33 & 1636.72 & $\mathrm{O}-\mathrm{H}$ Bend vibration \\
\hline $1035-1050$ & Alcohol & 1049.31 & 1018.00 & 1042.00 & Si-O stretch \\
\hline $950-910$ & carboxylic acid & - & 919.79 & 920.00 & $\mathrm{O}-\mathrm{H}$ bend \\
\hline \multirow[t]{2}{*}{$900-670$} & Aromatic & - & 759.00 & 788.11 & Si-O stretching vibration \\
\hline & Phenol & - & 686.69 & 683.45 & O-H stretching vibration \\
\hline \multirow[t]{2}{*}{$500-300$} & Alkyl halides & - & 545.00 & $543 . .43$ & Al-O-Si vibration \\
\hline & Alkyl halides & - & 460.29 & 461.86 & Si-O-Si deformation \\
\hline
\end{tabular}

$\mathrm{RK}=$ Raw Kaolinite, HKC $=$ Hydroxyliron (III) Kaolinite Composite.

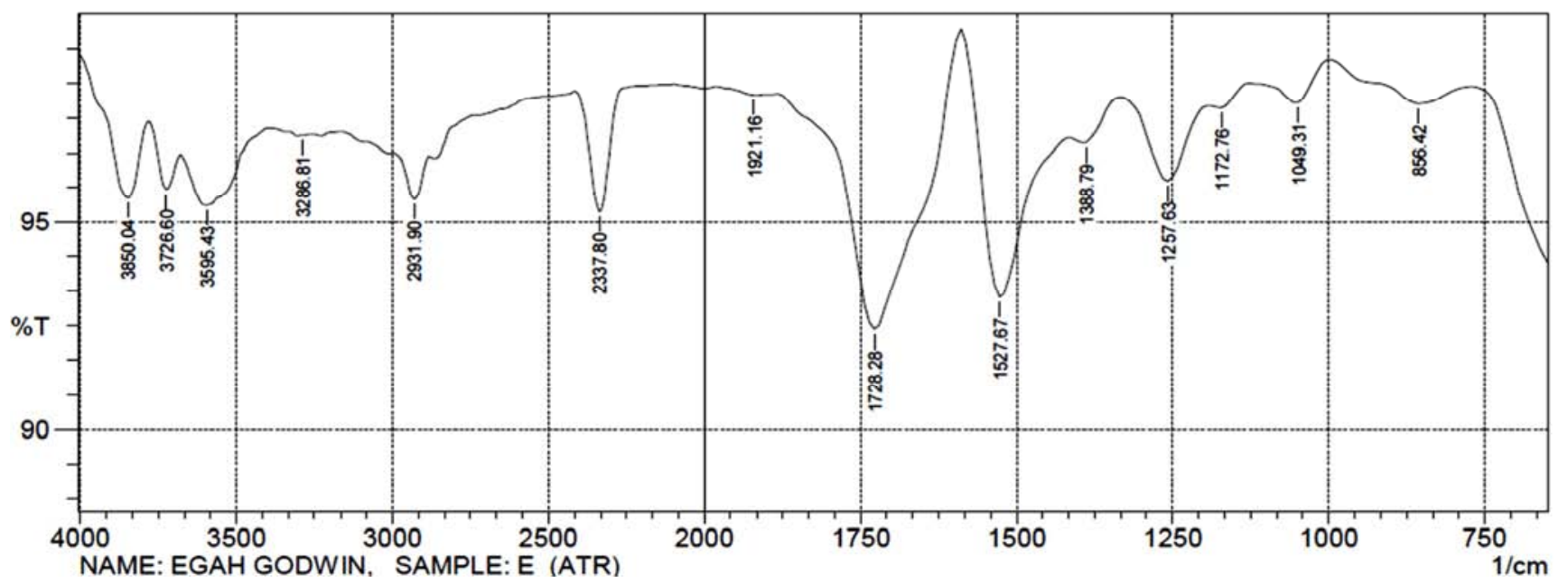

Figure 1. FTIR Spectrum of Hydroxyiron (III) ( $\left.\mathrm{Fe}(\mathrm{OH})_{3}\right)$. 


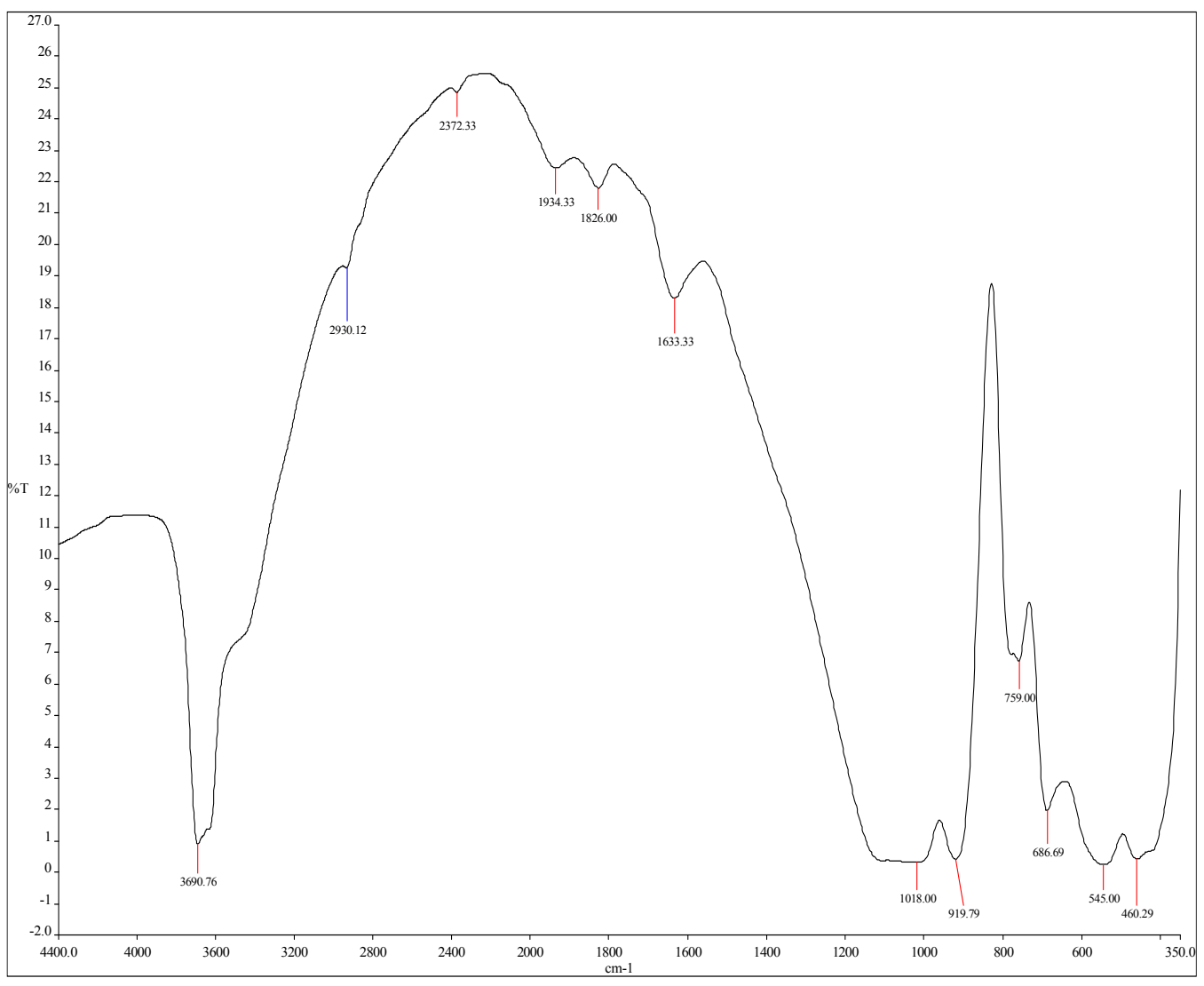

Figure 2. FTIR Spectrum of Raw Kaolin (RK).

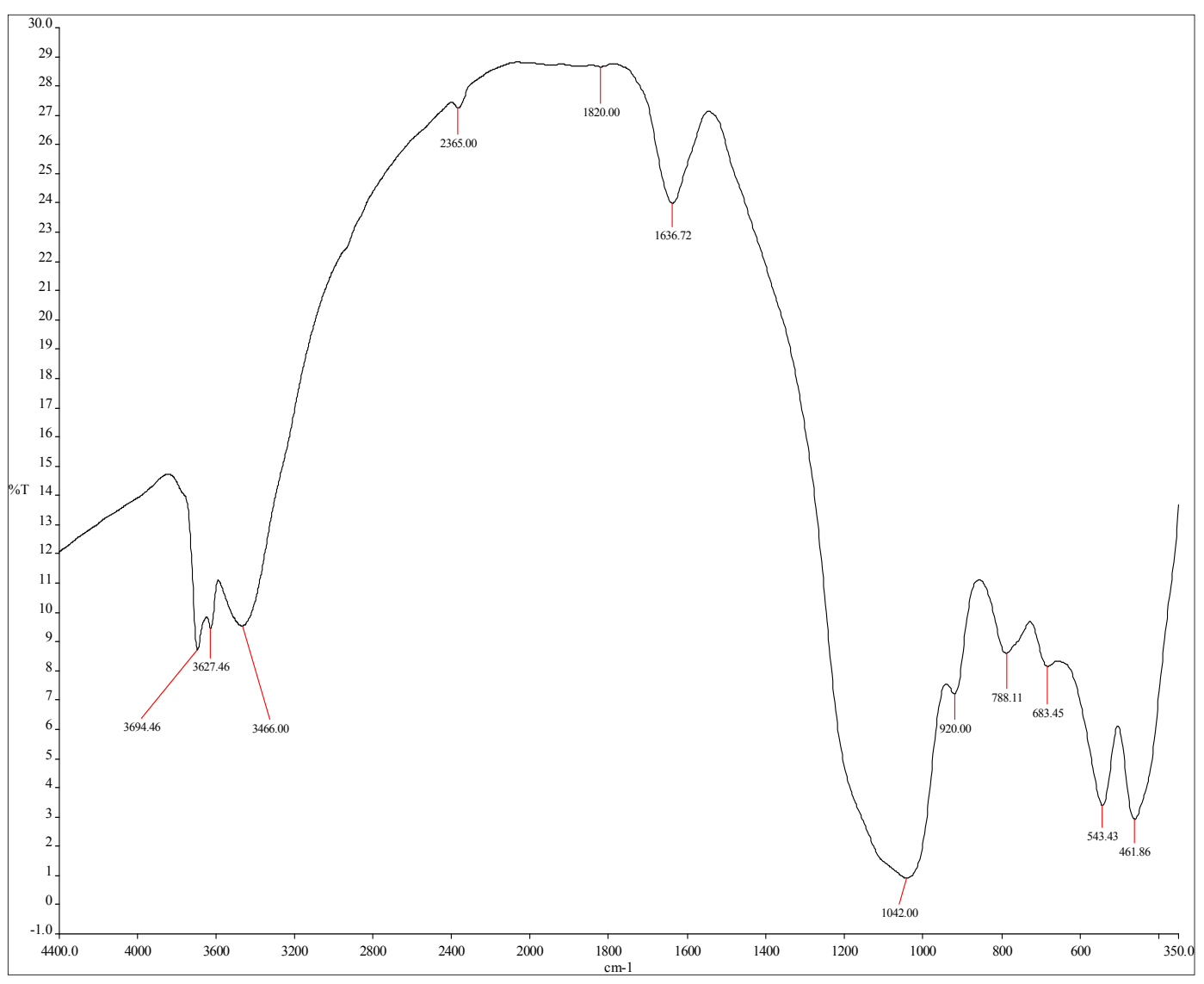

Figure 3. FTIR Spectrum of Hydroxyliron (III) - Kaolin Composite (HKC). 


\subsection{XRF Analysis of Adsorbents}

The chemical composition of the adsorbents was determined using Sky-ray Instrument (EDX3600B) X-Ray Florescence instrument (XRF), performed at a voltage of 40 $\mathrm{kv}$ and current of $350 \mu \mathrm{A}$. Results in Table 3 showed the chemical composition of raw kaolinite and Hydroxyiron (III) - kaolinite composites of which the raw kaolinite RK sample was mainly composed of $\mathrm{SiO}_{2}(54.9770 \%)$ and $\mathrm{Al}_{2} \mathrm{O}_{3}$ (39.4447\%) indicating a high grade kaolinite mineral $\left(\mathrm{Al}_{2} \mathrm{O}_{3} \cdot 2 \mathrm{SiO}_{2} \cdot 2 \mathrm{H}_{2} \mathrm{O}\right)$ for the removal of phenol and cadmium [3]. Some impurities such as $\mathrm{P}_{2} \mathrm{O}_{5}(0.2758 \%), \quad \mathrm{SO}_{3}$

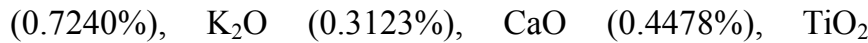
(0.4696\%), $\mathrm{MnO}(0.0007 \%), \mathrm{Fe}_{2} \mathrm{O}_{3} \quad(1.2764 \%), \quad \mathrm{ZnO}$ (0.0857\%), $\mathrm{SnO}_{2}(1.0514 \%)$ and $\mathrm{Sb}_{2} \mathrm{O}_{3}(0.9345 \%)$ also exist in small amount [5].

XRF analysis of hydroxyiron (III) - kaolinite composite (HKC) in Table 3 showed that it was mainly composed of $\mathrm{SO}_{3}$ (42.1455\%), $\mathrm{SiO}_{2}$ (22.4080\%) and $\mathrm{Al}_{2} \mathrm{O}_{3}(20.5065 \%)$ indicating a reduction in weight due to decomposition of impurities during calcination at $600^{\circ} \mathrm{C}$ for $1 \mathrm{hr}$ [3]. The presence of $\mathrm{SO}_{3}$ may be due to substitution of $\mathrm{Al}^{3+}$ and $\mathrm{Si}^{4+}$ ions with $\mathrm{SO}_{4}^{2-}$.

Table 3. X-Ray Florescence Chemical Composition of the Adsorbents.

\begin{tabular}{|c|c|c|c|c|c|c|c|c|c|c|c|c|}
\hline OXIDE & $\mathbf{A l}_{2} \mathbf{O}_{3}$ & $\mathrm{SiO}_{2}$ & $\mathrm{P}_{2} \mathrm{O}_{5}$ & $\mathrm{SO}_{3}$ & $\mathbf{K}_{2} \mathbf{O}$ & $\mathrm{CaO}$ & $\mathrm{MnO}$ & $\mathrm{Fe}_{2} \mathrm{O}_{3}$ & $\mathrm{ZnO}$ & $\mathrm{SnO}_{2}$ & $\mathrm{Sb}_{2} \mathrm{O}_{3}$ & Total \\
\hline RK (wt\%) & 39.45 & 54.97 & 0.28 & 0.72 & 0.31 & 0.45 & 0.00 & 1.28 & 0.09 & 1.05 & 0.94 & 99.53 \\
\hline HKC (wt\%) & 20.51 & 22.41 & 1.70 & 42.15 & 0.31 & 0.39 & 0.00 & 9.59 & 0.15 & 1.43 & 1.37 & 100 \\
\hline
\end{tabular}

\subsection{Scanning Electron Microscopy of Adsorbents}

To determine the surface morphology of the adsorbent Scanning electron microscope (SEM - JEOL, JSM 7600 F) was used. The sputter coater was operated in an argon atmosphere using a current of $6 \mathrm{~mA}$ for $3 \mathrm{~min}$. SEM results showed interaction between the adsorbate and adsorbent granule interface in an experimental condition [30]. Figures 4-6 showed the SEM results for RK, TAK and HKC respectively.

Results of RK in Figure 4, showed a smaller size of particles with fine porous structure in nano-scale range. Figure 5, indicates micrograph for thermally activated kaolinite (TAK) showing macro-pores with well-developed crystalline structure. The external surface shows a rough area having different irregular shapes of varying sizes and pore diameters distributed over the surface. Figure 6, which indicates the micrograph of hydroxyiron (III) - kaolinite composites (HKC), showed a compact, tubular crystals and mono-disperse particle size on the surface, which increases the surface active site of the adsorbent for adsorption [5]. In comparison of RK and TAK, it can be concluded that the hydroxyiron (III) - kaolin composite (HKC) provides more reactive sites, which enhanced adsorption capacity [3].

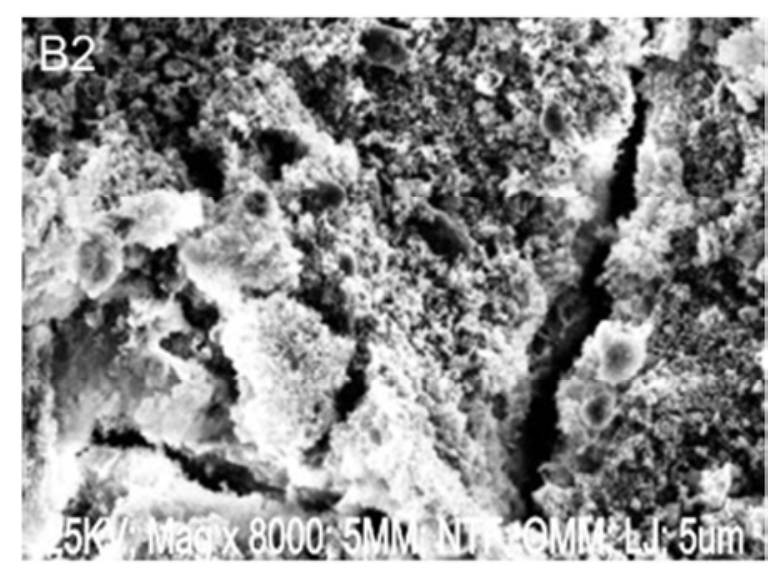

Figure 4. Scanning Electron Microscope (SEM) of RK.

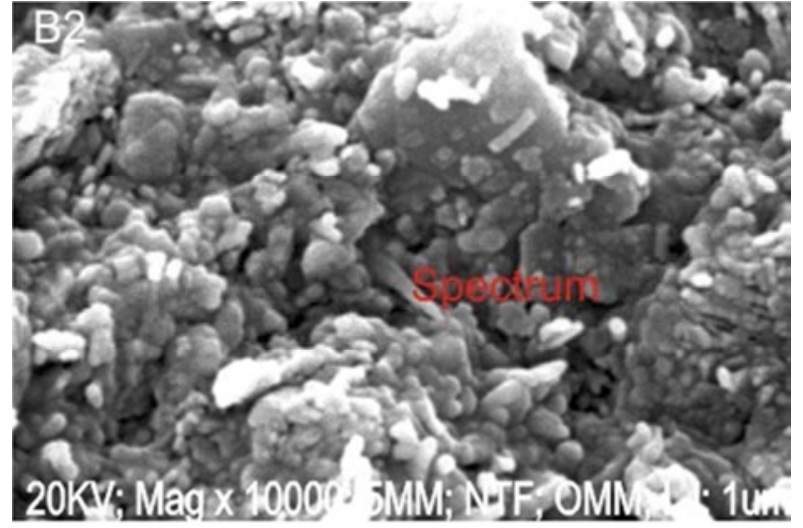

Figure 5. Scanning Electron Microscope (SEM) of TAK.

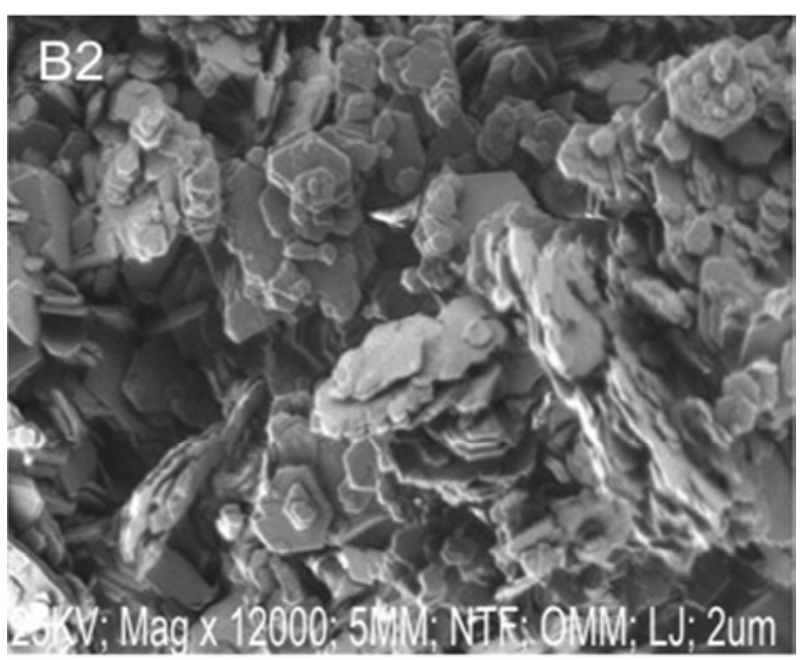

Figure 6. Scanning Electron Microscope (SEM) of HKC.

\subsection{Batch Adsorption Experiments}

\subsubsection{Effect of Initial Solution pH on Adsorption of Phenol and Cadmium}

Figure 7, showed the effect of $\mathrm{pH}$ on adsorption of phenol which is by electrostatic attraction [3]. Result shows the highest percentage removal for $\mathrm{RK}$ to be $55.784 \%$ at $\mathrm{pH}$ of 9 , 
TAK to be $56.096 \%$ at $\mathrm{pH}$ of 7 and HKC to be $63.936 \%$ at $\mathrm{pH}$ of 7. From the result for all the adsorbents it was observed that optimum removal was achieved between $\mathrm{pH} 7$ and 9 which may be due to increase in electrostatic attraction between the adsorbate and adsorbents [31]. The ionization degree of phenol depends on the $\mathrm{pH}$ values of the solution [3]. Results showed that at $\mathrm{pH}$ of 7 and 9, phenol dissociate into phenolate $\left(\mathrm{C}_{6} \mathrm{H}_{5} \mathrm{O}^{-}\right)$, which was then adsorbed by the positively charged adsorbents surfaces [3]. However, as the $\mathrm{pH}$ approaches alkaline at 11, there was an observed decrease from 55.784\% - 26.776\%, 56.096\% - 40.104\%, 63.936\%$46.216 \%$ for RK, TAK and HKC respectively due to repulsion between the adsorbate - adsorbent surface, as the negative charges decreased [32].

From results given in Figure 8 for all the adsorbents, the optimum $\mathrm{pH}$ for cadmium was observed at 2. The highest percentage removal for RK, TAK and HKC was found to be $45.734 \%, 49.798 \%$ and $73.918 \%$ respectively. A decrease in percentage removal was observed as the $\mathrm{pH}$ increased from 2-11, for RK, TAK and HKC from $45.734 \%-31.770 \%$, $49.798 \%-37.924 \%$ and $73.918 \%$ - 53.386\% respectively. The high adsorption at $\mathrm{pH} 2$ showed that cation exchange between the adsorbents - adsorbate was favored by acidic $\mathrm{pH}$ [4]. At strongly acidic $\mathrm{pH}$, protons are readily available which undergoes cation exchange with cadmium ions. But as the $\mathrm{pH}$ increases, the acidity reduces; hence decreasing the number of protons present for cation exchange therefore leading to decreased in adsorption [3].

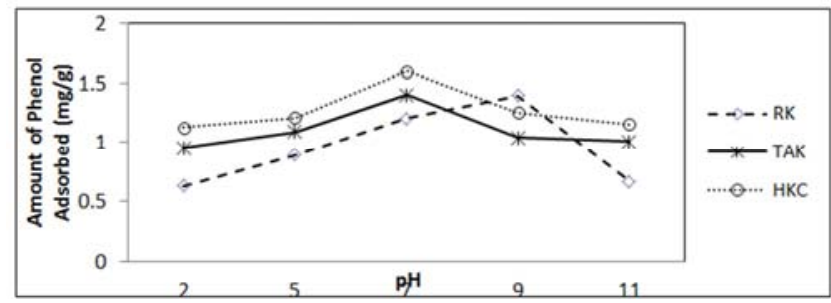

Figure 7. Effect of Initial Solution pH on Aqueous Phase Adsorption of Phenol on the Adsorbents.

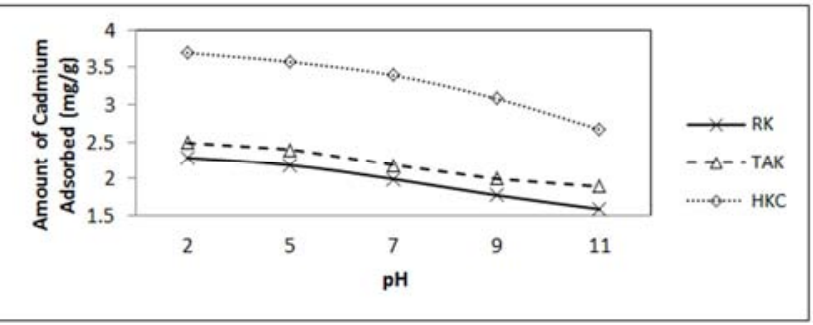

Figure 8. Effect of Initial Solution pH on Aqueous Phase Adsorption of Cadmium on the Adsorbents.

\subsubsection{Effect of Adsorbent Dosage on Phenol and Cadmium Adsorption}

The effect of adsorbent dosage on the removal of phenol and Cadmium is seen in Figure 9 for RK, TAK and HKC. Percentage removal showed that as the amount of adsorbent increases from $0.5 \mathrm{~g}$ to $2.5 \mathrm{~g}$, the percent removal of phenol increased from $23.012 \%$ - $62.056 \%$ for RK, $27.868 \%$ -
$68.484 \%$ for TAK and $32.732 \%-70.052 \%$ for HKC this was due to increase in surface negative charges that favors sorbent-solute interactions [10].

For cadmium as shown in Figure 10, it was observed that as the dosage increases also, that the percentage removal increased from $44.198 \%$ - 55.750\%, 47.656\% - 57.950\%, $53.786 \%-69.992 \%$ for RK, TAK and HKC respectively. This may be attributed to large surface area available for adsorption [33]. This enables adsorption to take place [34]. From their percentage removal it was observed that $\mathrm{HKC}$ is a more potent adsorbent than TAK, and RK.

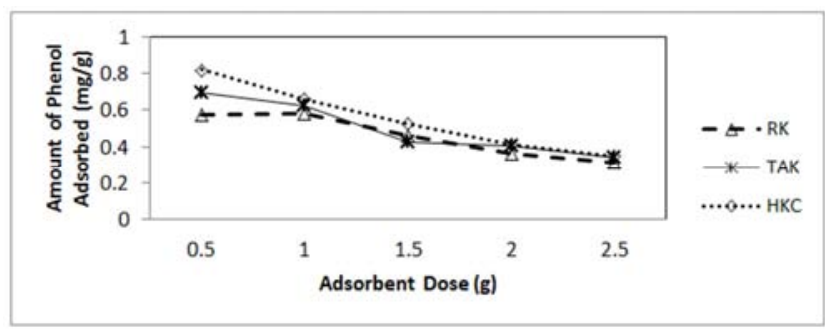

Figure 9. Effect of Adsorbent Dose on Adsorption of Phenol.

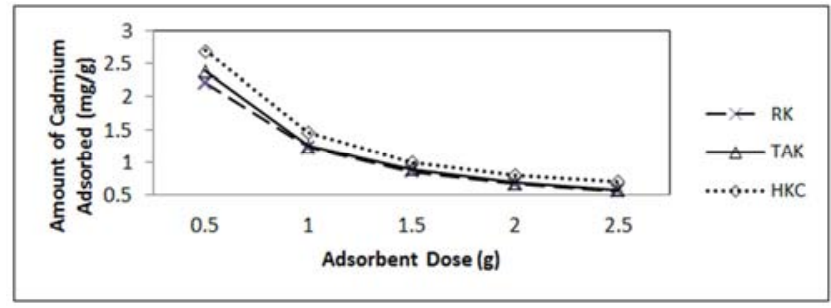

Figure 10. Effect of Adsorbent Dose on Adsorption of Cadmium.

\subsubsection{Effect of Phenol and Cadmium Initial Concentration on Adsorption}

Results in Figure 11-12 showed the effect of initial concentration on adsorption. Figure 11, showed that as phenol increases from $5 \mathrm{mg} / \mathrm{L}-25 \mathrm{mg} / \mathrm{L}$, the amount of phenol adsorbed increases from $0.202-1.377 \mathrm{mg} / \mathrm{g}, 0.292$ $1.424 \mathrm{mg} / \mathrm{g}, 0.300-1.514 \mathrm{mg} / \mathrm{g}$ for RK, TAK and HKC respectively. Result showed that, the available sites for adsorption decreases as the concentration increases. This is connected with the competitive diffusion process of the phenol through the pores in kaolinite [35].

Similar trend was observed for cadmium in Figure 12, in which as the initial concentration of cadmium increases from $10 \mathrm{mg} / \mathrm{L}-50 \mathrm{mg} / \mathrm{L}$, the amount of cadmium increases from $0.194-1.999 \mathrm{mg} / \mathrm{g}, 0.270-2.098 \mathrm{mg} / \mathrm{g}, 0.360-2.400 \mathrm{mg} / \mathrm{g}$ for RK, TAK and HKC respectively. As increase in concentration made cadmium ion to have strong competition for adsorption sites [36]. Here, the active sites of the adsorbent are able to adsorbed more cadmium ions as compared to lower concentrations [37]. From the results, it was observed that the HKC adsorbent is more potent than the RK and TAK which may be due to their high surface area and porosity [3]. 


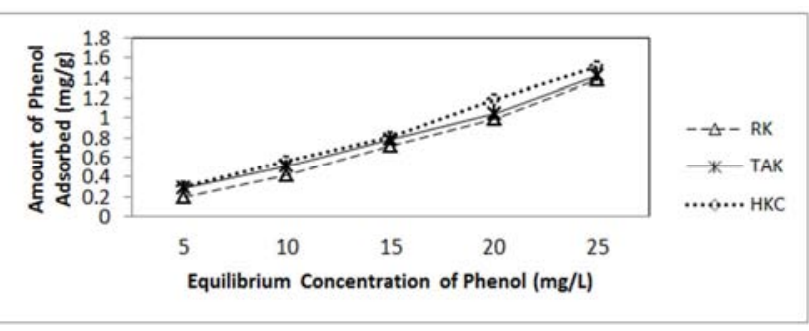

Figure 11. Effect of the Initial Concentration on Adsorption of Phenol.

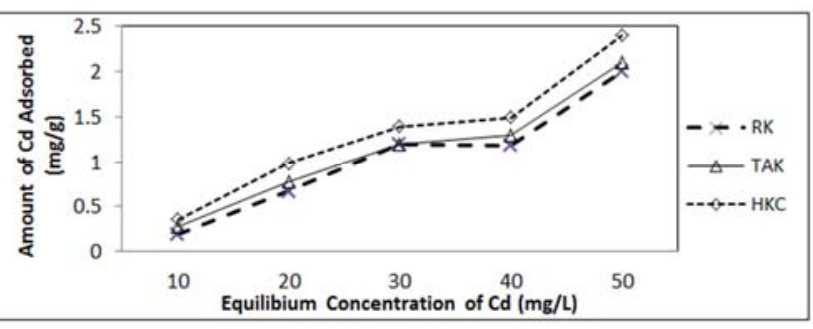

Figure 12. Effect of the Initial Concentration on Adsorption of Cadmium.

\subsubsection{Effect of Temperature on Adsorption of Phenol and Cadmium}

Figures 13-14 shows the effect of temperature adsorption of phenol and cadmium. Results on Figures 13 showed that as the temperature increases from $298 \mathrm{~K}-328 \mathrm{~K}$ that the percentage removal of Phenol increases from $41.512 \%$ $63.780 \%, 42.296 \%-66.600 \%$ and $44.024 \%-71.228 \%$ for RK, TAK and HKC respectively. The characteristic increase in absorption of phenol may be due to increase in oxidation or ionization of phenol due to increase in temperature which made the negative phenolate charges available for the active sites of the adsorbent [38].

In the case of Cadmium in Figures 14, it was observed that as the temperature increases from $298 \mathrm{~K}-318 \mathrm{~K}$ an increase in percentage removal was observed from $45.972 \%$ - $55.992 \%$ for RK, $49.996 \%$ - $59.950 \%$ for TAK, $53.836 \%$ $63.996 \%$ for HKC which may be attributed to increase collision between the adsorbent and the adsorbate [39]. A decrease was observed for all adsorbents as the Temperature is further increased to $328 \mathrm{~K}$ which may be due to reduction of the available adsorption sites caused by gradually saturation of the active sites [40]. Comparatively, HKC was found to be a more potent adsorbent than the RK and TAK which may be attributed to its porosity and high surface charge.

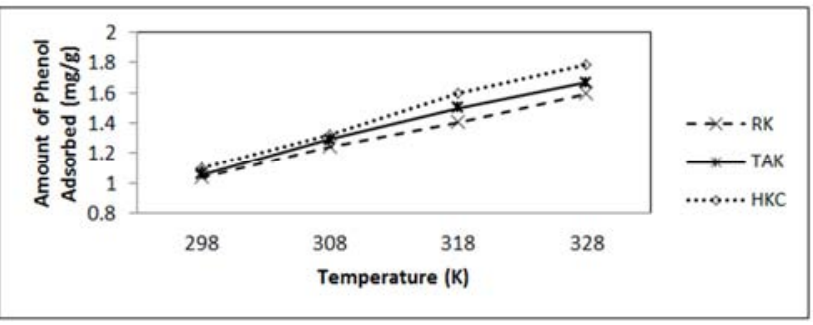

Figure 13. Effect of Temperature on Adsorption of Phenol.

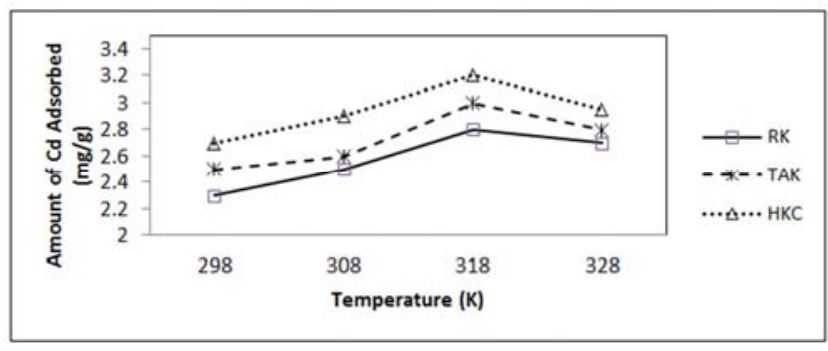

Figure 14. Effect of Temperature on Adsorption of Cadmium.

\subsubsection{Effect of Contact Time on Phenol and Cadmium}

From results on effect of contact time on adsorption phenol and Cadmium shown Figures 15-16, it was observed that adsorption capacity increased at all times from (10 - 60 mins) until equilibrium was attained at 60 minutes. Adsorption rate appeared to be very fast in the first 10 minutes, which could be explained to high number of adsorption sites from the start [5]. As the time increased, the adsorption sites became gradually saturated until equilibrium was attained at 60 minutes [41]. For phenol at 60 minutes, the highest adsorption capacity of 1.403 $\mathrm{mg} / \mathrm{g}, 1.699 \mathrm{mg} / \mathrm{g}$ and $1.890 \mathrm{mg} / \mathrm{g}$ were observed for RK, TAK and $\mathrm{HKC}$ respectively.

Similarly for cadmium, the highest adsorption capacity of $2.083 \mathrm{mg} / \mathrm{g}, 2.291 \mathrm{mg} / \mathrm{g}$, and $3.187 \mathrm{mg} / \mathrm{g}$ was observed for RK, TAK and HKC respectively. This may be due to the gradual saturation of the active sites by ions as the contact time increased [36]. Studies on the Characterization and application of kaolinite clay as solid phase extractor for removal of copper ions from environmental water samples reported similar results [5].

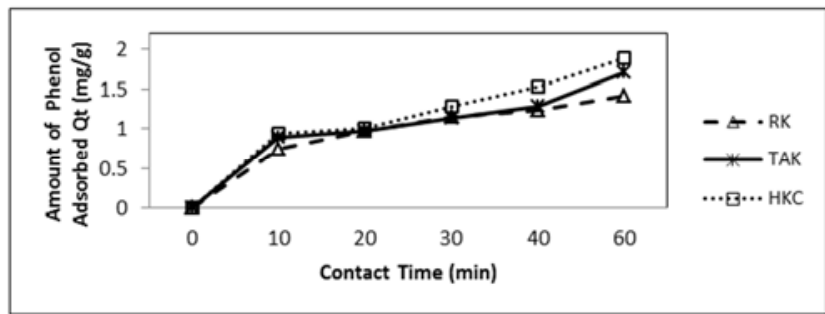

Figure 15. Effect of contact time on phenol uptake by adsorbent.

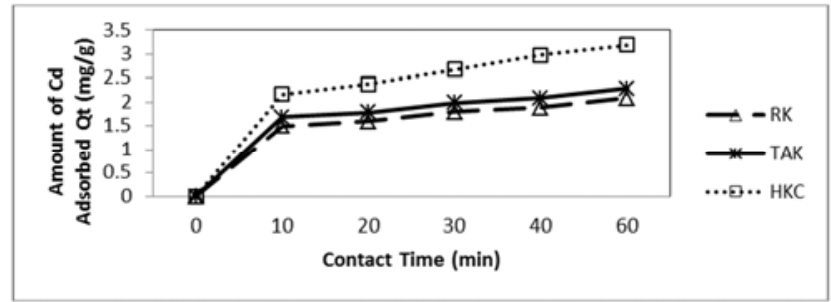

Figure 16. Effect of contact time on Cadmium uptake by Adsorbent.

\subsection{Adsorption Kinetic Model}

Data's obtained from the effect of contact time on adsorption of phenol and cadmium were fitted into the kinetic models as shown in Table 4 and Figures 17-18. The results showed that the adsorption of phenol and cadmium on RK, 
TAK and HKC could be described by both first and second order kinetic model. From their correlation coefficient $\mathrm{R}^{2}$, it was observed that the Blanchard pseudo-second order gave a better fittings for both phenol and cadmium with $\mathrm{R}^{2}$ values ranging from $0.908-0.997$ and $0.993-0.994$ respectively as compared with the Lagergren pseudo-first order which gave lower $\mathrm{R}^{2}$ values ranging from (0.957-0.995) and (0.923-0.969) respectively and the pseudo-second order rate constants $\mathrm{K}_{2}$ were in the range $\left(0.016-0.040 \mathrm{~g} . \mathrm{mg}^{-1} \mathrm{~min}^{-1}\right)$ for phenol and (0.031-0.059 g. $\mathrm{mg}^{-1} \mathrm{~min}^{-1}$ for cadmium. The high value of $\mathrm{R}^{2}$ for the second - order shows that the pseudo second order best describes the whole adsorption processes indicating that chemisorption predominant on all adsorbents as the ratedetermining step [14]. From the kinetic data of phenol and cadmium onto RK, TAK and HKC as presented by the Blanchard pseudo-second order, the adsorption of cadmium was more favorable than phenol [3].

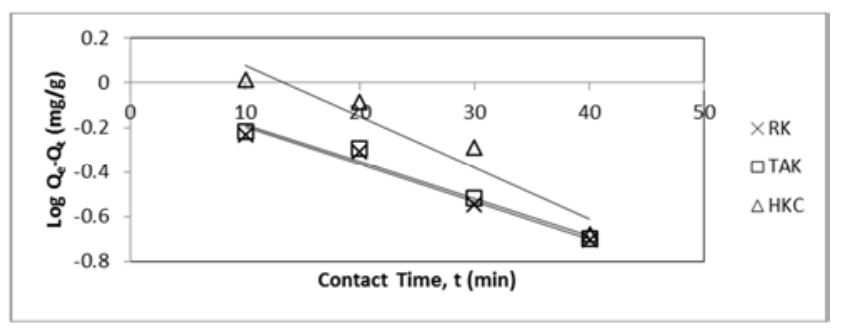

Figure 17. Lagergren Pseudo-First Order Kinetic Plots for Adsorbent on Cadmium.

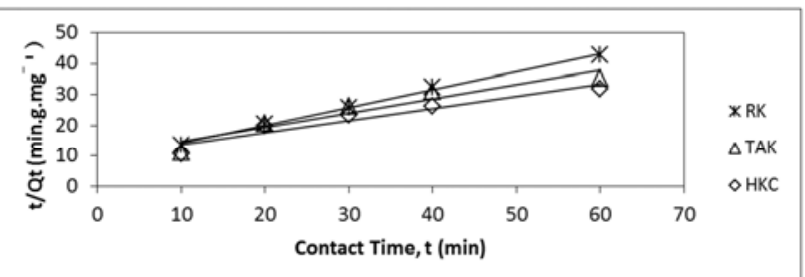

Figures 18. Blanchard Pseudo-Second Order Kinetic Plots for the Different Adsorbents on Phenol.

Table 4. Kinetic Parameter for Adsorption Lagergren First Order and Blanchard Second Order for Phenol and Cadmium.

\begin{tabular}{|c|c|c|c|c|}
\hline Adsorbate & Model & Adsorbent & & \\
\hline Phenol & First order & RK & TAK & HKC \\
\hline \multirow{8}{*}{ Phenol } & $\mathrm{K}_{1}\left(\mathrm{Lmin}^{-1}\right)$ & 0.046 & 0.023 & 0.035 \\
\hline & $\mathrm{Qe}(\mathrm{mg} / \mathrm{g})$ & 1.052 & 1.086 & 1.626 \\
\hline & $\mathrm{R}^{2}$ & 0.995 & 0.959 & 0.957 \\
\hline & Second order & & & \\
\hline & $\mathrm{K}_{2}\left(\mathrm{~g} \cdot \mathrm{mg}^{-1} \mathrm{~min}^{-1}\right)$ & 0.040 & 0.021 & 0.016 \\
\hline & Qe (mg/g) & 1.719 & 2.154 & 2.537 \\
\hline & $\mathrm{R}^{2}$ & 0.997 & 0.908 & 0.916 \\
\hline & $\mathrm{h}\left(\mathrm{gmg}^{-1} \min ^{-1}\right)$ & 0.118 & 0.099 & 0.102 \\
\hline \multirow[t]{4}{*}{ Cadmium } & First order & & & \\
\hline & $\mathrm{K}_{1}\left(\operatorname{Lmin}^{-1}\right)$ & 0.038 & 0.038 & 0.053 \\
\hline & Qe (mg/g) & 0.927 & 0.954 & 2.037 \\
\hline & $\mathrm{R}^{2}$ & 0.969 & 0.969 & 0.923 \\
\hline \multirow[t]{5}{*}{ Cadmium } & Second order & & & \\
\hline & $\mathrm{K}_{2}\left(\mathrm{~g} \cdot \mathrm{mg}^{-1} \min ^{-1}\right)$ & 0.059 & 0.059 & 0.031 \\
\hline & $\mathrm{Qe}(\mathrm{mg} / \mathrm{g})$ & 2.294 & 2.501 & 3.617 \\
\hline & $\mathrm{R}^{2}$ & 0.993 & 0.994 & 0.993 \\
\hline & $\mathrm{h}\left(\mathrm{gmg}^{-1} \mathrm{~min}^{-1}\right)$ & 0.309 & 0.370 & 0.408 \\
\hline
\end{tabular}

\subsection{Adsorption Isotherm Models}

\subsubsection{Langmuir Isotherms Model for Adsorption of Phenol and Cadmium}

This model is used on assumption that adsorption occurs at homogeneous sites and forms a monolayer [33]. The theoretical values of langmuir constants $Q_{m}$ and $\mathrm{K}_{\mathrm{L}}$ were calculated from the slope and intercept of a linear plot of 1/Qe versus 1/Ce respectively. Results for phenol in Table 5 and Figures 19, gave the maximum adsorption capacity, $\mathrm{Q}_{\mathrm{m}}$ values of $(1.399 \mathrm{mg} / \mathrm{g}, 3.376 \mathrm{mg} / \mathrm{g}$ and $7.047 \mathrm{mg} / \mathrm{g})$ for $\mathrm{RK}$, TAK and HKC respectively. Similar results were obtained for cadmium in Table 5, with values of $(0.703 \mathrm{mg} / \mathrm{g}, 1.564$ $\mathrm{mg} / \mathrm{g}, 3.140 \mathrm{mg} / \mathrm{g}$ ) for RK, TAK and HKC respectively. These values indicates the total number of binding sites are available for adsorption [42]. The high values for HKC $(7.047 \mathrm{mg} / \mathrm{g}),(3.140 \mathrm{mg} / \mathrm{g})$ for phenol and cadmium showed that HKC has high value of total binding sites for phenol and cadmium than RK, and TAK which could be attributed to their porosity and high conductivity [14]. From the values of the langmuir isotherm calculated from the experimental data with the dimensionless constant called separation factor, $\mathrm{R}_{\mathrm{L}}$, the values were found to be all $<1$ and $>0$ indicating a favourable adsorption for all adsorbent [43]. The results of correlation coefficients $\mathrm{R}^{2}$ on the adsorption of Phenol and Cadmium as described by both Langmuir and Freundlich isotherms in Table 5, the Langmuir gave the highest $\mathrm{R}^{2}$ value of (0.998) for phenol and (0.943) for cadmium than the Freundlich which gave (0.982), (0.917) for phenol and cadmium. Results for both Phenol and Cadmium indicated that the experimental data best obeyed Langmuir than Freundlich isotherm. This means that the Langmuir model best described the experimental data and can be concluded based on this model that the active sites on the adsorbents surface were homogeneously distributed and form a monolayer adsorption [16].

\subsubsection{Freundlich Isotherms Model for Adsorption of Phenol and Cadmium}

Freundlich assumes that adsorption takes place on heterogeneous surface of the adsorbent [33]. From the Freundlich equation stated earlier in equation 1 , the $\mathrm{K}_{\mathrm{F}}$ and $\mathrm{n}_{\mathrm{F}}$ are obtained from slope and intercept of the plot of $\log \mathrm{Q}_{\mathrm{e}}$ versus $\log \mathrm{C}_{\mathrm{e}}$. For Freundlich model results in Table 5 and Figures 20 , for phenol, a high $\mathrm{K}_{\mathrm{F}}$ value of $(0.141 \mathrm{mg} / \mathrm{g})$ was obtained for $\mathrm{HKC}$, than the rest adsorbent, presented HKC to be more potent for adsorption of phenol [43]. Similar trends were obtained for cadmium which gave HKC values to be $(0.058 \mathrm{mg} / \mathrm{g})$ making it a better adsorbent which could be due to their porosity [44]. From Table 5, adsorption is favourable for values $>1$ and unfavourable for $<1$ for the adsorption intensity $n_{F}$ [17]. This means that adsorption is favourable for phenol. Adsorption is homogenous rather than heterogeneous due to the lower $\mathrm{R}^{2}$ values obtained from Freundlich isotherm [33]. From the results, the $1 / \mathrm{n}$ values found to be $>1$ showed that the adsorption processes are unfavourable while those $<1$ are fovourable for adsorption of both phenol and cadmium [3]. 


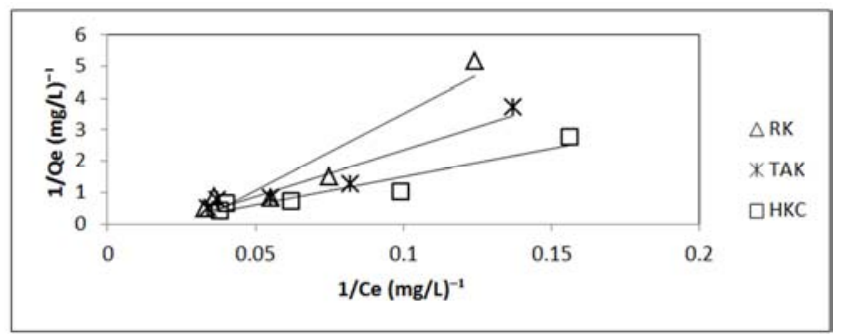

Figure 19. Langmuir Isotherm for Cadmium

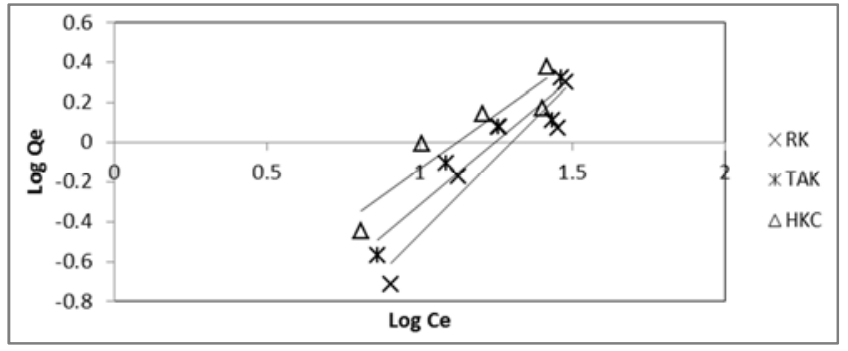

Figure 20. Freundlich Isotherm for Cadmium

Table 5. Isotherm Parameters for Phenol and Cadmium Adsorption on Adsorbents.

\begin{tabular}{|c|c|c|c|c|}
\hline Adsorbate & Model & Adsorbent & & \\
\hline Phenol & Langmuir & RK & TAK & HKC \\
\hline \multirow{9}{*}{ Phenol } & $\mathrm{Q}_{\mathrm{m}}(\mathrm{mg} / \mathrm{g})$ & 1.399 & 3.376 & 7.047 \\
\hline & b (L/mg) & 0.042 & 0.044 & 0.022 \\
\hline & $\mathrm{R}^{2}$ & 0.998 & 0.969 & 0.984 \\
\hline & $\mathrm{R}_{\mathrm{L}}$ & 0.826 & 0.820 & 0.901 \\
\hline & Freundlich & & & \\
\hline & $1 / \mathrm{n}$ & -0.280 & 0.920 & 0.990 \\
\hline & $\mathrm{n}_{\mathrm{F}}$ & 3.566 & 1.087 & 1.011 \\
\hline & $\mathrm{R}^{2}$ & 0.005 & 0.962 & 0.970 \\
\hline & $\left.\mathrm{K}_{\mathrm{F}}((\mathrm{mg} / \mathrm{g}) \mathrm{L} / \mathrm{mg}) 1 / \mathrm{n}\right)$ & 0.084 & 0.137 & 0.141 \\
\hline \multirow[t]{5}{*}{ Cadmium } & Langmuir & & & \\
\hline & $\mathrm{Q}_{\mathrm{m}}(\mathrm{mg} / \mathrm{g})$ & 0.703 & 1.564 & 3.140 \\
\hline & $\mathrm{b}(\mathrm{L} / \mathrm{mg})$ & 0.029 & 0.022 & 0.018 \\
\hline & $\mathrm{R}^{2}$ & 0.909 & 0.931 & 0.899 \\
\hline & $\mathrm{R}_{\mathrm{L}}$ & 0.775 & 0.823 & 0.851 \\
\hline \multirow[t]{5}{*}{ Cadmium } & Freundlich & & & \\
\hline & $1 / \mathrm{n}$ & 1.540 & 1.285 & 1.102 \\
\hline & $\mathrm{n}_{\mathrm{F}}$ & 0.649 & 0.779 & 0.907 \\
\hline & $\mathrm{R}^{2}$ & 0.890 & 0.917 & 0.874 \\
\hline & $\left.\mathrm{K}_{\mathrm{F}}((\mathrm{mg} / \mathrm{g}) \mathrm{L} / \mathrm{mg}) 1 / \mathrm{n}\right)$ & 0.010 & 0.025 & 0.058 \\
\hline
\end{tabular}

\subsection{Thermodynamic Parameter for Adsorption of Phenol and Cadmium}

The calculated values of thermodynamic parameters used to determine the spontaneity of adsorption are listed in Table 6 and Figures 21-22. Results from the table gave all values of $\Delta \mathrm{H}^{0}$ to be all positive ranging from $\left(2.777-29.766 \mathrm{kJmol}^{-1}\right)$ and from $\left(8.679-14.623 \mathrm{kJmol}^{-1}\right)$ for phenol and cadmium respectively. This presents endothermic reaction as dominates adsorption process, in which chemisorption dominates physisorption [16]. Comparatively, the higher values of $\mathrm{HKC}$ are an indication that their endothermic reactions are higher than their corresponding RK and TAK.

From the results, the high positive values of $\Delta \mathrm{S}^{0}$ ranging from (62. 648-80.179 $\mathrm{kJ} / \mathrm{molK})$ and (10.562-31.926 $\mathrm{kJ} / \mathrm{molK}$ ) for phenol and cadmium are attributed to high degree of disorderliness at the solid- liquid interface during adsorption which indicate the adsorbents - adsorbate affinity in aqueous phase [20]. Also, the positive values of Gibbs free energy $\Delta \mathrm{G}^{0}$ ranging from $(3.468-4.324 \mathrm{~kJ} / \mathrm{mol})$ and $(4.470$ $5.597 \mathrm{~kJ} / \mathrm{mol}$ ) for phenol and cadmium, is an indication of non-spontaneous reaction [18].

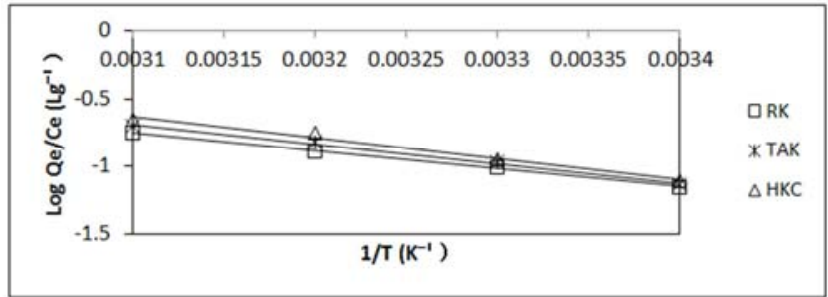

Figure 21. Van't Holf Plots for Adsorption of Phenol.

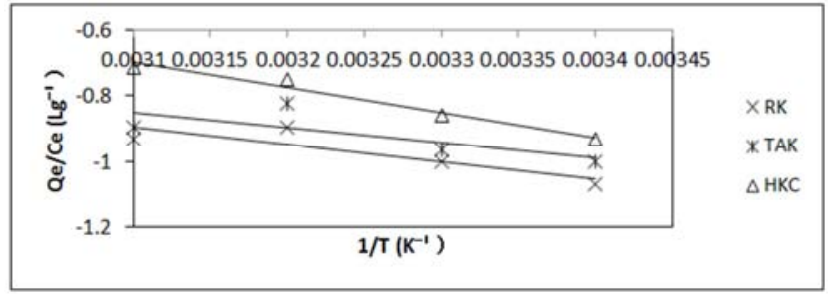

Figure 22. Van't Holf Plots for Adsorption of Cadmium.

Table 6. Thermodynamic Parameters of Adsorption for Phenol and Cadmium.

\begin{tabular}{|c|c|c|c|c|c|}
\hline Adsorbate & Adsorbents & $\Delta \mathrm{H}(\mathrm{kJ} / \mathrm{mol} .1000)$ & $\Delta \mathrm{S}(\mathrm{kJ} / \mathrm{molK})$ & $\mathbf{R}^{2}$ & $\Delta G(k J / m o l .1000)$ \\
\hline \multirow[t]{3}{*}{ Phenol } & RK & 24.872 & 62.648 & 0.998 & 4.324 \\
\hline & TAK & 2.777 & 72.884 & 0.996 & 3.865 \\
\hline & $\mathrm{HKC}$ & 29.766 & 80.179 & 0.986 & 3.468 \\
\hline \multirow[t]{3}{*}{ Cadmium } & RK & 9.999 & 13.843 & 0.758 & 5.597 \\
\hline & TAK & 8.679 & 10.562 & 0.567 & 5.321 \\
\hline & $\mathrm{HKC}$ & 14.623 & 31.926 & 0.967 & 4.470 \\
\hline
\end{tabular}

\subsection{Statistical Analysis}

One way analysis of variance (ANOVA) was carried out at $95 \%$ confidence interval in order to measure the significant difference between experimental HKC, RK and TAK as control using their percentage removal from their contact time. The model was found to be adequate for prediction if $\mathrm{P}$ value is lower than 0.05 , and then it indicates that the model is statistically significant [29].

From the result of the ANOVA for phenol, there is no significant mean difference between the means of RK, TAK, and HKC, since the p-value $(=0.566)$ is $>0.05$ level of significance. But for cadmium, there is significant mean 
difference between the means of RK, TAK, and HKC, since the $\mathrm{p}$-value $(=0.002)$ is $<0.05$ level of significance. From the Multiple Comparison Table, using LSD as post hoc test, the mean of $\mathrm{HKC}$ is significantly greater than the mean of TAK. Also the mean of $\mathrm{HKC}$ is significantly greater than the mean of RK. But the mean of TAK is not significantly different from the mean of RK.

\section{Conclusion}

Raw Kaolin (RK), thermally activated kaolinite (TAK) and Hydroxyiron (iii) - Kaolin Composite (HKC) exhibited good physicochemical attributes as adsorbents.

From this study it could be concluded that adsorption of phenol and cadmium are affected by initial $\mathrm{pH}$, adsorbent dosage, initial solution concentrations, temperature and contact time. From the investigation, adsorption capacity of phenol and cadmium decreased with increase in adsorbent dosage for RK, TAK and HKC. The $\mathrm{pH}$ 7-9 and $\mathrm{pH} 2$ was found to be the optimum $\mathrm{pH}$ for adsorption of phenol and cadmium respectively. For effect of initial solution concentration and temperature, it was found that adsorption capacity of RK, TAK and HKC increased with increased in concentration and temperature of phenol and cadmium.

Experimental data were found to fits the linearized Langmuir isotherm than the Freundlich isotherm for both phenol and cadmium, suggesting a monolayer adsorption. From the results it is found that chemisorption dominates the rate limiting step since Kinetic data fitted the pseudo-second order model than first order.

\section{References}

[1] Afaj H. A, Mohammad R. M and Mahmoud N. M. Removal of phenol from Industrial Effluents using Activated Carbon and Iraqi Porcelanite Rocks-A Comparative Study. Journal of Ministry of Science and Technology. 91, 2015, pp. 21-32.

[2] Bhole B. D, Ganguly B and Madhuram A. "Biosorption of Methyl Violet, Basic Fuschin and Their Mixture Using Dead Fungal Biomass", Research Communications Journal, 86, 2004, pp. 1641-1645.

[3] Sha'Ato R, Egah G. O and Itodo A. U. Aqueous phase abatement of phenol and cadmium using Hydroxyiron (III) calcined with bentonite. Fuw Trends in Science and Technology Journal. 3 (1), 2018, pp. 1-10.

[4] Dawodu F. A, Akpomie G. K and Ogbu I. Isotherm Modeling on the Equilibrium Sorption of Cadmium (II) from Solution by Agbani Clay. International journal of multidisciplinary sciences and engineering, 3 (9), 2012, pp. 9-14.

[5] Ahmed A. S, Tantawy A. M, Abdallah M. E and Qassim I. M. Characterization and application of kaolinite clay as solid phase extractor for removal of copper ions from environmental water samples. International Journal of Advanced Research. 3 (3), 2015, pp. 1-21.

[6] Srivastava R, Upreti R. K, Prasad K. N, Seth P. K and Chaturvedi, U. C. Suboptimal chlorine treatment of drinking water leads to selection of multidrug-resistant Pseudomonas aeruginosa. Ecotoxicology and environmental saftety journal. 58 (2), 2006, pp. 277-283.

[7] Rao P. S, Kalyani S, Reddy K. V. N. S and Krishnaiah A. Comparison of biosorption of nickel (II) and copper (II) ions from aqueous solution by sphaeroplea algae and acid treated sphaeroplea algae. Separation Science Technology. 40, 2011, pp. 3149-3165.

[8] Arellano-C'ardenas S, Gallardo-Vel'azquez T, Osorio-Revilla G, L'opez-Cort'ez M, del S and G'omez-Perea B. Adsorption of Phenol and Dichlorophenols from Aqueous Solutions by Porous Clay Heterostructure (PCH), Journal of Mexican Chemical Society. 49, 2005, pp. 287-291.

[9] Bhattacharyya K. G, SenGupta S, Sarma G. K. Interactions of the dye, rhodamine B with kaolinite and montmorillonite in water. Applied Clay Science. 99, 2014, pp. 7-17.

[10] Mohammad W. A, Fawwaz I. K and Akl A. M. Adsorption of lead, zinc and cadmium ions on polyphosphate-modified kaolinite clay. Journal of Environmental Chemistry and Ecotoxicology. 2 (1), 2010, pp. 001-008.

[11] Bansal R. C and Goyal M. Activated carbon adsorption. Boca Raton, CRC press Taylor and Francis group. 6000 broken sound parkway NW, suite 300 Boca Raton, FL, U. S. A, 2005, pp. $33487-2742$.

[12] Chen X. Modeling of Experimental Adsorption Isotherm Data. Open access Information. 6, 2015, pp. 14-22.

[13] Essomba S. J, Ndi Nsami J, Belibi B. P, Tagne M. G and Ketcha Mbadcam J. Adsorption of Cadmium (II) Ions from Aqueous Solution onto Kaolinite and Metakaolinite. Journal, Pure and Applied Chemical Sciences, 2 (1), 2014, pp. 11-30.

[14] Ajay K. A, Mahendra S. K, Chandrashekhar P. P, Ishwardas L. $\mathrm{M}$. Kinetics study on the adsorption of $\mathrm{ni}^{2+}$ ions onto fly ash. Journal of Chemical Technology and Metallurgy. 50 (5), 2015 , pp. 601-605.

[15] El-Dars E. S. M. F, Ibrahim M. H, Farag B. A. H, Abdelwahhab Z. M and Shalabi H. E. M. Preparation, Characterization of Bentonite Carbon Composite And Design Application In Adsorption Of Bromothymol Blue Dye. Journal of Multidisciplinary Engineering Science and Technology, 3 (1), 2016, pp. 3758-3765.

[16] Bai T. M, Komali K and Ventakeswarhi P. Equilibrium, kinetics and thermodynamic studies on biosorption of copper and Zinc from mixed solution by Erythrina Variegata orientalis leaf powder. India Journal of chemical Technology. 17, 2010, pp. 346-355.

[17] Dawodu F. A, Akpomie G. K and Ogbu I. The removal of cadmium (ii) ions from aqueous solution by the use of "afuze" bentonite: equilibrium, kinetic and thermodynamic studies. International Journal of Scientific \& Engineering Research. 3 (12), 2012, pp. 1-8.

[18] Jameel M. D, Hussien A. K and Nasser T. Removal of Cadmium Ions from Industrial Wastewater Using Iraqi Ceratophyllum Demersum. Al- Mustansiriyah Journal of Sciences, 32 (8), 2012, pp. 71-84.

[19] Kosmulski M. pH -dependent surface charging and points zero charge. iv update and new approach. Journal of Colloid and Interface Science. 337, 2009, pp. 439-448.

[20] Tan J, Zhang X, Wei X and Wang, L. Basic dye sorption on ONP fiber. Bioresources Journal. 7 (3), 2012, pp. 4307-4320. 
[21] Kibami D, Pongener C, Rao, K. S and Sinha D. Preparation and characterization of activated carbon from Fagopyrum esculentum Moench by $\mathrm{HNO}_{3}$ and $\mathrm{H}_{3} \mathrm{PO}_{4}$ chemical activation. Der Chemica Sinica. 5 (4), 2014, pp. 46-55.

[22] Okieimen C. O and Okieimen F. E. Enhanced metal sorption by groundnut (arachis hypogea) husks modified with thioglycollic acid. Bull. Piere Applied Science. 20, 2001, pp. 13-20.

[23] Bansode R. R. "Treatment of Organic and Inorganic Pollutants in Municipal Wastewater by Agricultural byproduct based Granular Activated Carbon (GAC)". Unpublished M. Sc. Thesis. Louisiana State University and Agricultural and Mechanical College: Alexandria, 2002.

[24] Abdus-Salam N and Buhari M. Adsorption of Alizarin and Fluorescein Dyes on Adsorbent prepared from Mango Seed. Pacific Journal of Science and Technology, 15 (1), 2014, pp. 232-244.

[25] Johari K, Saman N, Song S. T, Heng J. Y. Y and Mat H. Study of $\mathrm{Hg}$ (II) Removal from Aqueous Solution Using Lignocellulosic Coconut Fiber Biosorbents: Equilibrium and Kinetic Evaluation. 2014, pp.1198-1220.

[26] Aroke U. O, El-Nafaty U. A and Osha O. A. Properties and Characterization of Kaolin Clay from Alkaleri, North-Eastern Nigeria. International Journal of Emerging Technology and Advanced Engineering, 3 (11), 2013, pp. 387-392.

[27] Faye G, Bekele W and Fernandez N. Removal of Nitrate ion from Aqueous Solution by Modified Ethiopian Bentonite Clay. International journal of research in pharmacy and chemistry, 4 (1), 2014, pp. 192-201.

[28] Liew Y. M, Kamarudin H, Mustafa Al Bakri A. M, Luqman M, KhairulNizar I, Ruzaidi C. M and Heah C. Y. Processing and characterization of calcined kaolin cement powder. Constr. Building Material journal, 30. 2012, pp. 794-802.

[29] Moradi M, Dehpahlavan A, Kalantary R. R, Ameri A, Farzadkia $\mathrm{M}$ and Izanoo $\mathrm{H}$. Application of modified bentonite using sulfuric acid for the removal of hexavalent chromium from aqueous solutions. Environmental Health Engineering and Management Journal. 2 (3), 2015, pp. 99-106.

[30] Naswir M, Arita S, Marsi and Salni. Characterization of Bentonite by XRD and SEM-EDS and Use to Increase PH and Color Removal, Fe and Organic Substances in Peat Water. 1 (4), 2013, pp. 313-317.

[31] Bolat F, Govori S, Haziri A, Spahiu S and Faiku F. "Used Tea Waste Adsorption For Removal of Phenol From Synthetic and Kosovo Industrial Waste-water”. International journal, Environmental Application \& Science, 1, 2010, pp. 63-67.

[32] Denizli A, Ozkan G and Ucar M. Removal of chlorophenols from aquatic systems with dye affinity microbeads. Separation and Purification Technology, 24 (1-2), 2001, pp. 255-62.
[33] Nanganoa L. T, Ketcha J. M and Ndi J. N. Kinetic and Equilibrium Modeling of the Adsorption of Amaranth from aqueous solution onto Smectite Clay. Research Journal of Chemical Sciences. 4 (2), 2014, pp. 7-14.

[34] Gandhi N, Sirisha D, Asthana S and Manjusha A. Adsorption Studies of Fluoride on Multani Matti and Red Soil, Resources Journal on Chemical Sciences, 2 (10), 2012, pp. 32-37.

[35] Nassef E and Eltaweel Y. Adsorption of Phenol from Aqueous Solutions by Local Egyptian Bentonite. Journal of American Science. 8 (8), 2012, pp. 581-589.

[36] Bhattacharyya K. G, Gupta S. S. Removal of $\mathrm{Cu}$ (II) by natural and acid-activated clays: an insight of adsorption isotherm, kinetics and thermodynamics. Desalination, 272, 2011, pp. 66-75.

[37] Bayat B. Comparative study of adsorption properties of Turkish fly ashes I. The case of nickel (II), copper (II) and zinc (II). Journal Hazard. Material, 95, 2002, pp. 251-273.

[38] Jin w, Hongzhu M, Jie Y, Shanshan W, Wenyan H and Xiaoli $\mathrm{H}$. Studies on phenol removal from wastewater with CTABmodified bentonite supported $\mathrm{KMnO}_{4}$ Journal of Water Reuse and Desalination, 22, 2013, pp. 233-241

[39] Kannan, N and Veemaraj T. "Removal of Lead (II) Ions By Adsorption Onto Bamboo Dust and Commercial Activated Carbons: A Comparative Study”, Elec. Journal Chemistry 6 (2), 2009, pp. 247-256.

[40] Ennigrou D. J, Gzara L, Ben Romdhane M. R and Dhahbi M. Cadmium removal from aqueous solution by polyelectrolyte enhanced ultrafiltration. Desalination, 246 (1-3), 2009, pp. 363-369.

[41] Riebe B, and Bunnenberg C. "Influence of Temperature PreTreatment and High-Molar Saline Solutions on the Adsorption Capacity of Organo-Clay Minerals", Physics and Chemistry of the Earth. 32, 2007, pp. 581-587.

[42] Tan P. L, Wong C. L, Ong S. T and Hi S. L. Equilibrium and kinetic studies for Basic yellow 11 removals by Sargassum binderi, Journal Applied science. 9 (17), 2009, pp. 3005-3012.

[43] Krishna H. R and Swamy S. V. V. A. Physico-Chemical Key Parameters, Langmuir and Freundlich isotherm and Lagergren Rate Constant Studies on the removal of divalent nickel from the aqueous solutions onto powder of calcined brick. International Journal of Engineering Research and Development. 4 (1), 2012, pp. 29-38.

[44] Bousba S and Meniai H. A. Adsorption of 2-Chlorophenol onto Sewage Sludge based Adsorbent: Equilibrium and Kinetic Study. Chemical Engineering Transactiions, 35, 2013, pp. 859-864. 